\title{
Political dispute in Poland in the eyes of Facebook slacktivists
}

\begin{abstract}
This text is a report from research on selected aspects of the crisis of democracy in Poland. The problem of the analysis focuses on questions about the attitude of the participants in the political dispute towards opponents, the possibility (and method) of reaching an agreement and the assessment of the situation. I chose the area of analysis considering social media a transparent platform for political dispute (especially during the SARS-CoV-2 pandemic). The essence of the research was to find respondents clearly involved in the political dispute. I choose Facebook, among the other things, because this platform creates a place of many actively operating thematic groups which gathers supporters of particular political options. This fact facilitate reaching respondents with the preferred characteristics. The survey was conducted in the period 13/12/2020 to 25/01/2021 on the basis of the author's form consisting of 15 questions. The research sample consists of 220 respondents: 126 women and 94 men aged 14 to 72 years old. Appropriately for the nature of the variables and the sample size, the contingency coefficient and the Kruskal-Wallis test were calculated, together with the statistical significance of the obtained results. All analyzes were performed on the basis of SPSS software version 26 and Microsoft Excel.
\end{abstract}

Key words: democracy crisis, hate speech, slacktivism, social media

\section{Introduction}

B oth, the quality of democracy determined by various indicators (the level of human rights respect, freedom of the press, minority rights, economic freedom, etc.: Economist Intelligence 2019; Reporters Without Borders, 2020; Freedom House Reports, 2020), and the simple observation of contemporary political discourse, indicate a clear presence of crisis. This text deals with the crisis of democracy in Poland, however it should be understood as a global phenomenon. The issue of monitoring and the crisis of democracy is perceived today in almost all countries recognized as consolidated democracies (Antoszewski, Herbut, 2001, p. 25) and is undertaken both in science and journalism. The topic is also present in Polish literature as well as in academic and political discourse. ${ }^{1}$ Despite the extensive literature on the issue, there is still no clear findings as to its key elements.

A characteristic component of each crisis is the occurrence of an axial conflict and the accompanying, derived conflict situations. The problem has been raised before (Huntington, 2006), but relatively recently it manifested itself in a globally materialized form: around the middle of the second decade of the 21 st century, although of course this time point is an arbitrary indication here. Each conflict situation, in turn, is accompanied by

1 The crisis of liberal consensus in the European dimension is discussed, among others, by Chantal Mouffe, Anna Pałubicka, or Jürgen Habermas (Mouffe, 2005; Pałubicka, 2013; Habermas, 2007). 
a specific war rhetoric, experienced today by every researcher of selected aspects of Polish politics. The intensification of political competition, especially in the area of digital media, prompted the undertaking of this research task. The problem of the analysis focuses on questions about the attitude of the participants in the political dispute towards opponents, the possibility (and method) of reaching an agreement and the assessment of the situation. As the area of analysis, I chose social media because during the SARS$\mathrm{CoV}-2$ pandemic they are the most transparent platform for political dispute. Observation of the ubiquitous hate speech in the analyzed area and the results of my previous observations (Pawlak, 2014; 2016) did not allow expecting conciliatory results. In a sense, however, the analysis leads to positive conclusions for the democratic process.

The essence of the research was to find respondents clearly involved in the political dispute. Contemporary participation in political culture (as well as in various other areas of social activity) is increasingly the form of so-called slacktivism, ${ }^{2}$ therefore it manifests mainly in electronic form. This state of affairs is exacerbated by the SARS-CoV-2 virus pandemic. The ICT space is also a hate speech area. In this field, however, the source of hate is not the media, representatives of political parties or official factors, but most often ordinary citizens: users of social media - slacktivists. Some of them are also copywriters, web commentators, communication managers etc., employed by political parties or institutions, often called (but not always rightly) internet trolls. Summarizing, I wanted to analyze the opinions of the most politically engaged social media users. Slacktivism refers to a wide set of activities related to various fields of social activity: these activities are primarily electronic in nature, although their effects and/or causes are often real (e.g. charitable activities, court judgments, political decisions, etc.). In the context of this paper, I focus on two coexisting dimensions of this concept: political slactivism and the one related to the need of sympathy and antipathy expression (Christensen, 2011). Using the title category, it is possible to distinguish a specific part of users, for whom the manifestation of political orientation seems to be the main (but not the only) activity in social media.

The analysis was focused on Facebook due to the fact that users of this medium are among the most involved in political slacktivism. Although Facebook is not a platform dedicated primarily to the political debate (similar to for example to Twitter, which has already resigned from offering paid political ads in 2019: Dziermański, 2019), it is a place that concentrates the most active users within dedicated thematic groups. Both Facebook and Twitter are a space allowing observation of the phenomenon of hate speech. The difference between these media, however, is that on Twitter, a large proportion of politically active users remain anonymous, while on Facebook most of them acts under real names. Facebook is also a place of many actively operating thematic groups which gathers supporters of particular political options. This fact facilitate reaching respondents with the preferred characteristics. The survey was conducted in the period 13/12/2020 to 25/01/2021 on the basis of paper/Word documents $(\mathrm{N}=38)$ and electronic online Google forms $(\mathrm{N}=182)$. The date of research start was selected intentionally and falls on the 39th anniversary of the introduction of the Martial law in Poland. It was on that day that I tried to reach as many

2 This term, created at the turn of the 20th and 21 st centuries, generally refers to the passive activism of the information society characterized by short thinking and passivity towards real reality. In this reaity most actions are limited to a virtual forms like clicking, sharing, liking, commenting etc. (Więckiewicz, 2013). 
respondents as possible from the most radical Facebook groups ${ }^{3}$ and a group of other users commonly known for their political involvement. The start of the survey on this symbolic anniversary was intended to increase the level of reflection of the respondents.

\section{Methodology}

The survey form consists of 15 questions. The first 4 questions concern demographic and social characteristics, correlated with the topic and purpose of the study (gender, age, education, political orientation). The next 6 questions were divided into three sections, 2 questions each, without emphasizing this division in the form. The first section applies to the nature and state of the political dispute in Poland. I wanted to find an answer to the question of how the respondents identifying themselves with various political dispute parties define the current situation. It is well known that right-wing politicians, activists, publicists and famous slacktivists are inclined to use military terms (war, conflict, confrontation), most often labeled with adjectives such as: civilization, ideological, etc.

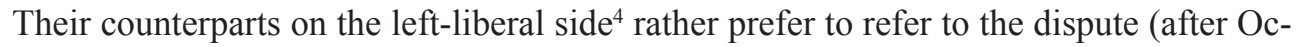
tober 22, obvious military rhetoric also entered here ${ }^{5}$ ) of a worldview, religious character (with a critical approach to religion) concerning the fight for broadly understood human rights and civil liberties. The purpose of these questions is therefore to obtain information on how the disputants themselves define the state in which they participate.

The next section allow to verify the question: do the political adversaries see a hypothetical possibility of reaching an agreement/compromise? The last section consists of two questions about the respondent's attitude towards political opponents: for a whole of opponents and for the opponents from their close people circle. Differences of views within families (both multigenerational and neolocal) are now an increasingly frequent phenomenon. It is also no coincidence that the research period coincides with the period of Christmas and New Year's Eve, which are traditionally the time of family gatherings. Despite epidemiological restrictions, it is a time of increased family contact, abounding in heated disputes about political reasons. Participants in such disputes engage in them primarily to convince their opponents of their arguments, and not to insult or ridicule them. The political "union" bond clashes here with the socially assigned "established" bond and the "natural" bond resulting from kinship (Rybicki, 1979). Therefore, this sec-

${ }^{3}$ A total of 20 politically formatted Facebook groups, such as: "The right side of the Internet," "March 8, day of the victims of feminism," "Beetroot juice," "Women's hell."

${ }^{4}$ It should be remembered that the classical boundaries of the political and ideological spectrum are now fluid and often questioned. Besides, the debate on the relationship between ideology and political doctrines and programs seems far from over. And it is despite attempts made more or less from the end of the 19th century - especially after the Second World War - to announce the "end of ideology." In the scientific form, this thesis was promoted, among others, by by Edward Shils, Raymond Aron, Seymour Lipset, Daniel Bell and Francis Fukuyam (Zuba, 2015, p. 20).

${ }^{5}$ After the ruling of the Constitutional Tribunal of October 22, 2020, a series of anti-government protests began in Poland. The Tribunal ruled that the possibility of an abortion due to a serious and irreversible disability of the fetus or an incurable disease that threatens its life is unconstitutional. Both the protesters and their opponents, as well as the socio-political circles supporting both sides, assessed the situation at the time directly as war (Kaczyński, 2020; Szczepankowski, 2020). 
tion allows to find an answer to the question: whether the respondents treat political opponents from the group of their relatives differently than the general political opponents.

The next questions concern the assessment of the tension in the political dispute and the proposed actions that could lead to agreement. Closely related to these questions is also the following section with questions 13 and 14 . These questions include, in fact, fundamental personal and political freedoms and rights, enshrined in Art. 38-56 (personal freedoms and rights) and art. 57-63 (political freedoms and rights) of the Polish Constitution. These rights are camouflaged in the survey only by non-disclosure their constitutional source. The aim of this section is to find out what respondents think about the scope of political and civil liberties, they allow for their political opponents. This question is related to the activity of many commentators of the political dispute - both public figures, authorities and celebrities, as well as ordinary citizens/users - who directly or in a veiled way opting for radical solutions. ${ }^{6}$ The radicalism of the postulated actions results from considering the current situation as a stalemate. This, in turn, can lead to frustration and a desire to take non-constitutional action.

The survey form ends with an open question referring to the respondents' ideas of the crisis solving. That question was placed after the previous questions, the auxiliary task of which was - apart from the basic cognitive function - to induce in-depth reflection in the respondent. That cogitation was supposed to be about regarding the attitude towards political opponents (question about feelings for all opponents and the following question about the same feelings for relatives of different political orientation), and respect for constitutional political and personal rights (questions 13 and 14). I assumed that completing the form should convince the respondent to a balanced final opinion.

First, the analyzes of the frequencies of all examined variables, expressed in tables, were performed. Then comparisons were made. Due to the subject of the paper and the purpose of the research, the analysis focused on selected variable configurations. It was examined whether the independent variable "political orientation" had a statistically significant influence on the values of selected dependent variables (assessment of the nature of the political dispute in Poland, assessment of the state of the political dispute in Poland, general assessment of political opponents, the possibility of reaching an agreement with political opponents, assessment of the tension of the political dispute in Poland, the idea of limiting political and civil rights and freedoms). Appropriately for the nature of the variables and the sample size, the contingency coefficient and the Kruskal-Wallis test were calculated, together with the statistical significance of the obtained results. All analyzes were performed on the basis of SPSS version 26 and Microsoft Excel.

\section{Frequency analysis}

There was 220 respondents participated in the study: 126 women and 94 men aged 14 to 72 years old. Less than a half of them (45.9\%) declared their political affiliation as left-wing, $24.1 \%$ as right-wing, $13.6 \%$ as the center and $12.3 \%$ as apolitical. The vast majority of the respondents indicated the nature of the political dispute in Poland as ideo-

${ }^{6}$ An extreme, albeit blunt example is e.g. the layer of comments under a post in a group „Rafał Trzaskowski - Common Poland Movement,” entitled: „Is there a civil war ahead?” Many of them express hope for the break out of a ta civil war (Jasińska, 2020). 
logical (40.9\%), then civilization (20.9\%) and multidimensional/complex (20.9\%). For further analysis, this variable was transformed, limiting the number of categories to five (ideological, civilization, generational/worldview, multidimensional/complex, other).

Table 1

The nature of the political dispute in Poland

\begin{tabular}{||l|c|c|}
\hline \multicolumn{1}{|c|}{ Answers } & Frequency (F) & \% \\
\hline Ideological & 90 & 40.9 \\
\hline Civilization & 46 & 20.9 \\
\hline Generational & 8 & 3.6 \\
\hline Worldview & 12 & 5.5 \\
\hline Multidimensional/complex & 46 & 20.9 \\
\hline Political & 5 & 2.3 \\
\hline Mafia & 3 & 1.4 \\
\hline Religious & 7 & 3.2 \\
\hline There is nothing unusual & 3 & 1.4 \\
\hline
\end{tabular}

Source: Elaboration based on own research.

In terms of the condition of political dispute in Poland respondents most often indicate war (41.4\%), increased political dispute (30.9) and crisis (17.7\%). For further analysis, the variable was transformed by combining three categories into one (ordinary political dispute + misunderstanding + there is nothing unusual $=$ ordinary political dispute) .

Table 2

The condition of political dispute in Poland

\begin{tabular}{||l|c|c|}
\hline \multicolumn{1}{|c|}{ Answers } & F & \% \\
\hline Ordinary political dispute & 4 & 1.8 \\
\hline Misunderstanding & 10 & 4.5 \\
\hline Increased political dispute & 68 & 30.9 \\
\hline Crisis & 39 & 17.7 \\
\hline War & 91 & 41.4 \\
\hline There is nothing unusual & 8 & 3.6 \\
\hline
\end{tabular}

Source: Elaboration based on own research.

In the section on the possibility and the will to reach agreement, the answers are somewhat differentiated: although $33.4 \%$ of the respondents believe that an agreement is possible to reach, only $12.7 \%$ believe that the other party wants such an agreement. Besides, $52 \%$ of the respondents don't see the possibility of reaching agreement, and $67.7 \%$ of the respondents don't see the will to reach agreement in their political opponents.

Table 3

Possibility of agreement with political opponents

\begin{tabular}{|l|r|c||}
\hline \multicolumn{1}{|c|}{ Answers } & F & \% \\
\hline Yes & 74 & 33.6 \\
\hline No & 116 & 52.7 \\
\hline I don't know & 30 & 13.6 \\
\hline
\end{tabular}

Source: Elaboration based on own research. 
Table 4

Does the political opponent want agreement

\begin{tabular}{|l|r|r||}
\hline \multicolumn{1}{|c|}{ Answers } & F & \% \\
\hline Yes & 28 & 12.7 \\
\hline No & 149 & 67.7 \\
\hline I don't know & 43 & 19.5 \\
\hline
\end{tabular}

Source: Elaboration based on own research.

We also find some differences in the section on the description of political opponents. They are most often described as ,,are wrong”: $27.3 \%$ of the answers on all political opponents and $29.5 \%$ of the answers on close/related people circle. Respondents attributed bad intentions to people from close circle much less frequently $(10 \%)$ than to all political opponents $(21.8 \%)$. Instead of ,bad intentions," the political opponents from close circle were described frequently as ,frustrated," than the general of political opponents (15.5\%). For the purposes of further analysis, I transformed the variables "description of political opponents" by reducing the number of categories to two: „relatively positive” and ,relatively negative.” The first category accumulates responses that do not attribute bad intentions to the other side (original responses: are wrong, are frustrated, have some right).

Table 5

Description of political opponents

\begin{tabular}{||l|c|c||}
\hline \multicolumn{1}{|c|}{ Answers } & F & \% \\
\hline Are wrong & 60 & 27.3 \\
\hline Are frustrated & 34 & 15.5 \\
\hline Have bad intentions (driven by low motives) & 48 & 21.8 \\
\hline Are stupid & 28 & 12.7 \\
\hline Have some right, but doing wrong & 37 & 16.8 \\
\hline Other & 12 & 5.5 \\
\hline Total & 219 & 99.5 \\
\hline Lack of data & 1 & .5 \\
\hline
\end{tabular}

Source: Elaboration based on own research.

Table 7

Description of political opponents from close people circle

\begin{tabular}{|l|c|c|}
\hline \multicolumn{1}{|c|}{ Answers } & F & \% \\
\hline Are wrong & 65 & 29.5 \\
\hline Are frustrated & 48 & 21.8 \\
\hline Have bad intentions (driven by low motives) & 22 & 10.0 \\
\hline Are stupid & 24 & 10.9 \\
\hline Have some right, but doing Wrong & 40 & 18.2 \\
\hline Other & 17 & 7.7 \\
\hline Ogółem & 216 & 98.2 \\
\hline Lack of data & 4 & 1.8 \\
\hline
\end{tabular}

Source: Elaboration based on own research. 
The vast majority of respondents as a way to achieve political agreement pointed to participation in a legal democratic process $(63.2 \% \%)$ and to the answer: ,wait for the mentality change" $(16.8 \%)$. Out of ,nondemocratic" options the most indications has „limit the freedom of political opponents” (6.8\%).

Table 8

The idea of how to achieve agreement

\begin{tabular}{|l|r|r||}
\hline \multicolumn{1}{|c|}{ Answers } & F & \% \\
\hline Participate in a legal democratic process & 139 & 63.2 \\
\hline Wait for the mentality change & 37 & 16.8 \\
\hline Impose own will by force & 6 & 2.7 \\
\hline Count on outside help & 6 & 2.7 \\
\hline Limit the freedom of political opponents & 15 & 6.8 \\
\hline Other & 17 & 7.7 \\
\hline
\end{tabular}

Source: Elaboration based on own research.

The respondents in general assess the level of tension in the political dispute in Poland on a scale of 0 to 10 rather high. The average answer was 7.86 , the median remained at 8 , and the most frequently given rating is 10 . Responses in the section on political and civil rights and freedoms in the vast majority $(86.7 \%)$ indicate the willingness of the respondents to respect these rights. For the purposes of further analysis, I transformed the data by combining the answers to questions 13 and 14 and limiting the number of categories. In this way, I obtained one dichotomous variable (Table 9).

Table 9

The idea of restriction of some personal freedoms of political opponents

\begin{tabular}{||l|c|c|}
\hline \multicolumn{1}{|c|}{ Answers } & F & \% \\
\hline No & 185 & 84.1 \\
\hline Yes & 35 & 15.9 \\
\hline Total & 220 & 100.0 \\
\hline
\end{tabular}

Source: Elaboration based on own research.

\section{Research hypotheses and their verification}

All of the following research hypotheses have been positively verified:

Research question: Does political orientation determine the approach to the problem of the political dispute in Poland?

H.1. Political orientation determines the assessment of the nature of the political dispute in Poland;

H.2. Political orientation determines the assessment of the state of the political dispute in Poland;

H.3. Political orientation determines the overall assessment of political opponents;

H.4. Political orientation determines the possibility of reaching an agreement with political opponents; 
H.5. Political orientation determines the assessment of the tension of the political dispute in Poland;

H.6. Political orientation determines the idea of limiting political and civil rights and freedoms.

Ad. H.1. More than half $(63.4 \%)$ of the respondents with a left-wing political orientation believe that the political dispute in Poland is ideological. This view is shared by $39.6 \%$ of respondents with a right-wing orientation. The centrally oriented respondents most often $(36.7 \%)$ indicates multidimensional/complex nature of the political dispute. The result of the contingency coefficient $(C=0.498)$ is statistically significant $(p=0.000)$. This means that there is a clear relationship between the analyzed variables. Crosstab column percentages are as follows:

Table 10

The nature of the political dispute in Poland * Political orientation

\begin{tabular}{|l|r|r|r|r|r||}
\hline \multirow{2}{*}{$\begin{array}{l}\text { The nature of the political dispute } \\
\text { in Poland X Political orientation }\end{array}$} & \multicolumn{4}{|c|}{ Political orientation } & \multirow{2}{*}{ Total } \\
\cline { 2 - 6 } & right & \multicolumn{1}{c|}{ left } & center & apolitical/other & \\
\hline Ideological & $39.6 \%$ & $63.4 \%$ & $10.0 \%$ & $5.7 \%$ & $41.1 \%$ \\
\hline Civilization & $28.3 \%$ & $11.9 \%$ & $26.7 \%$ & $28.6 \%$ & $20.5 \%$ \\
\hline Generational/worldview & $3.8 \%$ & $3.0 \%$ & $23.3 \%$ & $22.9 \%$ & $9.1 \%$ \\
\hline Multidimensional/complex & $20.8 \%$ & $16.8 \%$ & $36.7 \%$ & $20.0 \%$ & $21.0 \%$ \\
\hline Other & $7.5 \%$ & $5.0 \%$ & $3.3 \%$ & $22.9 \%$ & $8.2 \%$ \\
\hline Total & $100.0 \%$ & $100.0 \%$ & $100.0 \%$ & $100.0 \%$ & $100.0 \%$ \\
\hline
\end{tabular}

Source: Elaboration based on own research.

Ad. H.2. The majority (76.2\%) of respondents with left-wing political orientation believe that the political dispute in Poland is a war. Most of the respondents with a rightwing orientation (62.3\%) indicate increased political dispute. A similar opinion is shared by $46.7 \%$ of the respondents with a centrist orientation. The result of the contingency coefficient $(C=0.642)$ is statistically significant $(\mathrm{p}=0.000)$.

Table 11

The condition of political dispute in Poland * Political orientation

\begin{tabular}{|c|c|c|c|c|c|}
\hline \multirow{2}{*}{$\begin{array}{l}\text { The condition of political } \\
\text { dispute in Poland }\end{array}$} & \multicolumn{4}{|c|}{ Political orientation } & \multirow{2}{*}{ Total } \\
\hline & right & left & center & apolitical/other & \\
\hline Ordinary political dispute & $1.9 \%$ & $1.0 \%$ & $10.0 \%$ & $45.7 \%$ & $9.6 \%$ \\
\hline Increased political dispute & $62.3 \%$ & $11.9 \%$ & $46.7 \%$ & $25.7 \%$ & $31.1 \%$ \\
\hline Crisis & $17.0 \%$ & $10.9 \%$ & $30.0 \%$ & $28.6 \%$ & $17.8 \%$ \\
\hline War & $18.9 \%$ & $76.2 \%$ & $13.3 \%$ & & $41.6 \%$ \\
\hline Total & $100.0 \%$ & $100.0 \%$ & $100.0 \%$ & $100.0 \%$ & $100.0 \%$ \\
\hline
\end{tabular}

Source: Elaboration based on own research.

Ad. H.3. Most (50.5\%) of the respondents with a left-wing political orientation describes political opponents in a relatively negative way. Most right-wing respondents (77.4\%) describes political opponents in a relatively positive way. A similar opinion is 
shared by $56.7 \%$ of the respondents with a centrist orientation. The result of the contingency coefficient $(C=0.259)$ is statistically significant $(p=0.001)$.

Table 12

Description of general political opponents * Political orientation

\begin{tabular}{|c|c|c|c|c|c|}
\hline \multirow{2}{*}{$\begin{array}{l}\text { Description of general } \\
\text { political opponents }\end{array}$} & \multicolumn{4}{|c|}{ Political orientation } & \multirow{2}{*}{ Total } \\
\hline & right & left & center & apolitical/other & \\
\hline Relatively positive & $77.4 \%$ & $49.5 \%$ & $56.7 \%$ & $77.1 \%$ & $61.6 \%$ \\
\hline Relatively negative & $22.6 \%$ & $50.5 \%$ & $43.3 \%$ & $22.9 \%$ & $38.4 \%$ \\
\hline Total & $100.0 \%$ & $100.0 \%$ & $100.0 \%$ & $100.0 \%$ & $100.0 \%$ \\
\hline
\end{tabular}

Source: Elaboration based on own research.

Ad. H.4. The majority (71.3\%) of the respondents with a leftist political orientation believe that there is no possibility of agreement with political opponents. A similar opinion is shared by $66.7 \%$ of the respondents with a centrist orientation. Most of the respondents with a right-wing orientation $(60.4 \%)$ indicate that the possibility of agreement with political opponents exists. The result of the contingency coefficient $(\mathrm{C}=0.437)$ is statistically significant $(\mathrm{p}=0.000)$.

Table 13

Possibility of agreement with political opponents * Political orientation

\begin{tabular}{|l|r|r|r|r|r||}
\hline \multirow{2}{*}{$\begin{array}{c}\text { Possibility of agreement with } \\
\text { political opponents }\end{array}$} & \multicolumn{4}{|c|}{ Political orientation } & \multirow{2}{*}{ Total } \\
\cline { 2 - 5 } & right & \multicolumn{1}{c|}{ left } & center & apolitical/other & \\
\hline Yes & $60.4 \%$ & $18.8 \%$ & $30.0 \%$ & $40.0 \%$ & $33.8 \%$ \\
\hline No & $28.3 \%$ & $71.3 \%$ & $66.7 \%$ & $25.7 \%$ & $53.0 \%$ \\
\hline I don't know & $11.3 \%$ & $9.9 \%$ & $3.3 \%$ & $34.3 \%$ & $13.2 \%$ \\
\hline Total & $100.0 \%$ & $100.0 \%$ & $100.0 \%$ & $100.0 \%$ & $100.0 \%$ \\
\hline \hline
\end{tabular}

Source: Elaboration based on own research.

Ad. H.5. The Kruskal-Wallis test reveals the existence of statistically significant differences between the categories of the analyzed dependent variable, distinguished by the independent variable $(\mathrm{p}=0.000)$. Respondents with a left-wing political orientation rate the scale of political tension the highest. The lowest ratings come from apolitical respondents. This state is presented in the table of ranks and the box plot below:

The scale of tension in a political dispute: statistics

\begin{tabular}{|l|c||}
\hline \multicolumn{1}{|c|}{ Political orientation } & M \\
\hline Right & 6.21 \\
\hline Left & 9.27 \\
\hline Center & 7.47 \\
\hline Apolitical/other & 5.56 \\
\hline Total & 7.70 \\
\hline
\end{tabular}

Source: Elaboration based on own research. 
Diagram 1. The scale of tension in a political dispute: box plot

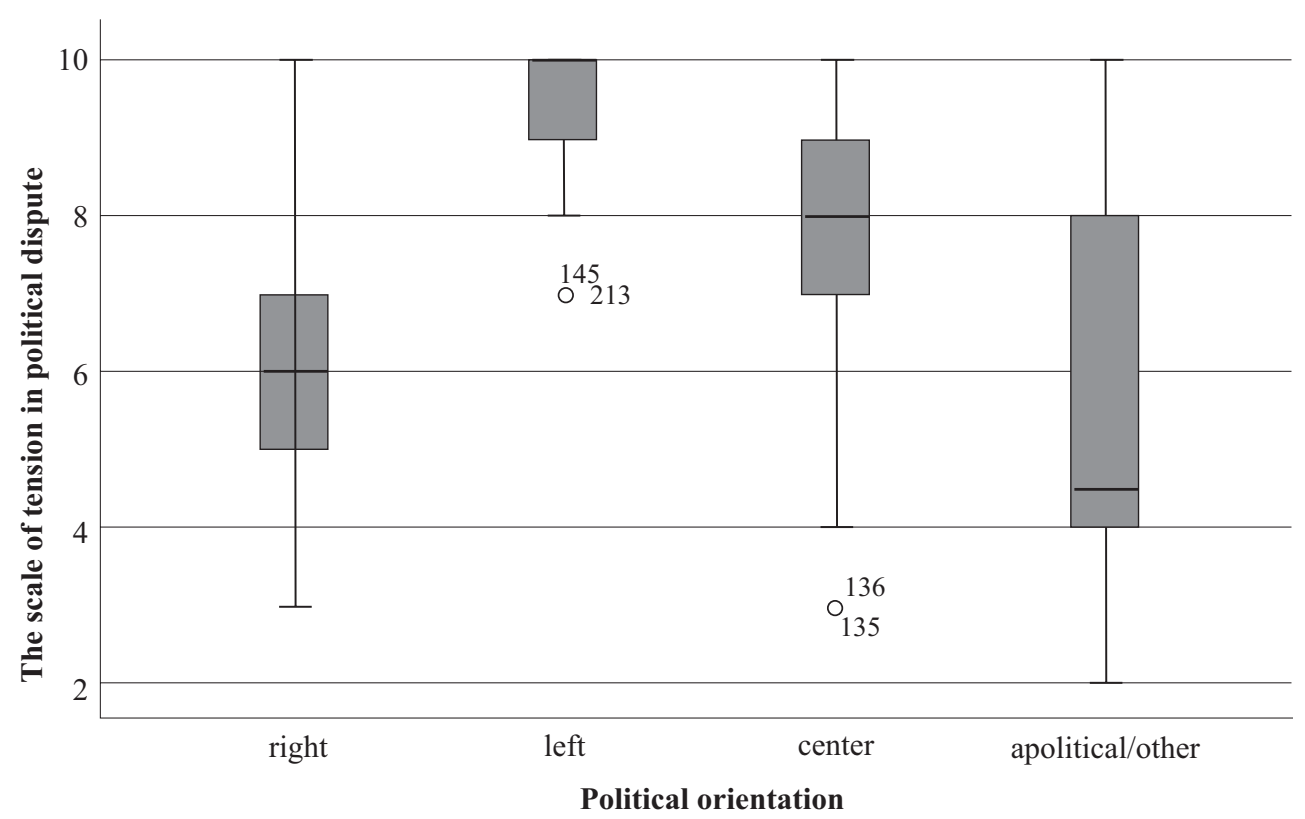

Source: Elaboration based on own research.

Ad. H.6. The majority of all respondents are against the restriction of any constitutional rights and freedoms to the other side of the political dispute. However, the percentage of supporters of limiting these rights is the highest in the group of respondents with left-wing views $(27.7 \%)$. The result of the contingency coefficient $(C=0.297)$ is statistically significant $(\mathrm{p}=0.000)$.

Table 15

The idea of restriction of some political and personal freedoms of political opponents * Political orientation

\begin{tabular}{|l|r|r|r|r|r||}
\hline \multirow{2}{*}{$\begin{array}{c}\text { The idea of restriction of some } \\
\text { political and personal freedoms } \\
\text { of political opponents }\end{array}$} & \multicolumn{4}{|c||}{ Political orientation } & \multirow{2}{*}{ Total } \\
\cline { 2 - 6 } & right & left & center & apolitical/other & \\
\hline No & $98.1 \%$ & $72.3 \%$ & $86.7 \%$ & $94.3 \%$ & $84.0 \%$ \\
\hline Yes & $1.9 \%$ & $27.7 \%$ & $13.3 \%$ & $5.7 \%$ & $16.0 \%$ \\
\hline Total & $100.0 \%$ & $100.0 \%$ & $100.0 \%$ & $100.0 \%$ & $100.0 \%$ \\
\hline
\end{tabular}

Source: Elaboration based on own research.

\section{Discussion}

Considering the demographics of Polish Facebook users (Ahlgren 2020; Rogulski 2020), the research group might to be a representative sample for the politically engaged Facebook user community. However, this estimation should be approached with caution 
and the analysis should be treated more like laboratory tests. The first important conclusion from the analysis is significant polarization of the research group. The political dispute seems to run here on the right-left axis, with the disappearance of the center. This reflects in some way the political situation in Poland and in the world, although this reference should be treated very generally: the relevant reevaluation in the broadly understood area of political phenomena supports the old postulate of redefining the classical meaning of many of them. This applies especially to the fundamental issues of ideology, social and political movements, doctrines and political parties, etc.).

Discussing the research results, should also take into account the general political profile of Facebook users. The majority of users of this medium are people with liberalleftist sympathies, although this advantage is not too great (Hitlin, Rainie, 2019; Wenzel, 2017; Kosiński, 2017). This study also confirms it in a way, although the number of users with conservative affiliations is clearly smaller than those with leftist views. Perhaps this reflects the modern trend of political sympathy transfer, and/or politically motivated transfer of social media users. It is also possible that the increased degree of political dispute contributes to the bipolarization of the electoral market, which is also fostered by the nature of digital participation in political culture (encapsulation of communities of views within information/filter bubbles).

The study confirms similar, earlier observations revealing a greater degree of aggressiveness and radicalism on the part of the supporters of the current democratic opposition, but at the same time reveals a number of positive - in an evaluative sense - results. The increased level of aggression on the part of the opposition supporters can be explained, on the one hand, by the natural behavior of the opposition electorates in general, ${ }^{7}$ on the other hand, by the general increase in emotional involvement in the political discourse across the entire political spectrum. It is worth noting that both tendencies have a global dimension and are determined, inter alia, by the process of digitization of political culture. On the one hand, it increases the participation of citizens in political culture [by supporting its participant type in the classical division proposed by Gabriel Almond and Sidney Verba (Almond, Verba, 1989)], on the other hand, it inflames the atmosphere of political dispute, which is one of the many social consequences of the influence of ICT. ${ }^{8}$ In addition, the SARS-CoV-2 virus pandemic has recently been a factor increasing social anxiety on a global scale.

A positive observation for the democratic process resulting from this analysis is the fact that most of the respondents do not pursue strictly forceful confrontation and/ or limitation of the constitutional rights and freedoms of political opponents. The answers to questions 9 and 10 concerning the description of political opponents can also

7 The democratic parliamentary system assigns the opposition a critical control role over the government and/or the parliamentary majority. Seeking to seize power, the opposition is the attacking side for the government's policy in whole or in selected aspects. Thus, it is the side of the political spectrum that is closer to the more confrontational rhetoric and strategy of actions, in which personalities with a certain degree of aggressiveness come to the fore (Wiatr, 1999). These kind of ,political gladiators" activates the opposition electorate with their charisma and radical slogans (Milbrath, Goel, 1977).

${ }^{8}$ Slactivism exposes political culture to the influence of all features of electronic participation, such as differentiation, fragmentation, acceleration, blurring of original contexts, visualization, etc. (Dijk van, 2010, s. 269). 
be interpreted in a similar way. Most of the respondents do not ascribe unambiguously negative features to their opponents $(61.8 \%)$, perceiving them rather as unaware people or victims of manipulation (e.g. the answers: they are wrong, they are frustrated, they are a bit right). In the conditions of an acute political conflict, manifestations of dehumanization of political opponents often occur in the public space. For politicians and voters of the other party are then assigned animal features (pig, dog, poultry, etc.), they are compared to criminals (Hitler, Stalin, Pol Pot, etc.), they are given negative species characteristics (e.g. parasite) and all audiovisual means to deny humanity. Despite the high level of aggression experienced today - especially in the layer of comments within politically formatted social media groups - the study does not reveal the widespread phenomenon of dehumanization of political opponents. This allows us to assume that the expressions of social media users - especially those focused within a specific community of values within the filter bubble (Pariser, 2011) - differ from their actual individual beliefs.

It is also worth noting that there are differences between the answers from questionnaires completed via electronic forms and traditional printed or Word forms. In both cases, only people with Facebook accounts were surveyed. The results collected from the traditional forms were of a much more conciliatory nature, a transparent example of which are the answers to questions 13 and 14 on political and civil rights and freedoms. In the case of on-line questionnaires, some respondents were in favor of restricting selected aspects of rights and freedoms. In the case of traditional forms, only single such statements were recorded. This may support the thesis that electronic communication with all its features (e.g. information bubbles) may contribute to increasing the level of aggression of participants. This, in turn, interestingly corresponds to the classic statement by Marshall McLuhan: "the medium is the message."

The last, open question of the survey provided a large amount of information, the analysis of which - due to the specificity of extensive open-ended questions - will constitute the matter of a separate text. I will describe here only the first conclusions from the general systematization of the research material. Most of those who speak out see a recipe for solving the crisis in dialogue and convincing political opponents by means of classically understood argumentation. The need for education in the field of knowledge about society, history, civic responsibility, etc. is also frequently indicated. These votes are dominant and come from respondents representing the full spectrum of the political scene. The nature and quality of the statements prove the will, and even the necessity, to seek common ground. The analysis of the answers to the open question contradicts the analysis of the content of thematic groups in social media, which prompts reflection about the already mentioned negative aspects of electronic communication. Virtual users concentrated within the Internet bubble constitute a community of views characterized by increasing encapsulation, the need to manifest beliefs and the radicalization of the message. Paradoxically, most users participate in discussions on Facebook (both in the group of friends, under popular posts and in thematic groups) under their own name. The statements are visible to the public or to your own network of friends. The anonymity factor is therefore quite limited here, which - as it turns out - is not an obstacle to the aggression of statements. Meanwhile, the material collected from anonymous surveys shows well-thought-out statements, mostly conciliatory and 
not related to the war rhetoric. It is interesting especially in view of the rich literature on the problem of the relationship between aggression and anonymity on the Internet, and the repeatedly proven hypotheses about the increase in aggression along with the sense of anonymity (Pawlak, Strzelecki, 2012). In the case of information bubbles, the opposite is visible, but more research will be needed to view the problem in more detail. In this sense, the results of this study can be treated as an impetus for further research.

In addition to substantive responses expressing the need for dialogue, education and a peaceful coexistence of supporters of individual political options, aggressive statements - contrary to the idea of democracy - were also noted. Interestingly, these statements come both from the respondents who - in questions 13 and 14 - considered the possibility of limiting political and civil liberties and rights, and from those who declared the inviolability of these rights. In total, there are $31 \mathrm{com}-$ ments that I have tentatively categorized as aggressive/unconstitutional, compared to 71 substantive/conciliation and 22 neutral comments. As already signaled, a certain justification for a higher level of aggression (which is revealed, among others, in the answers to question no. 15) among the opponents of the current parliamentary majority (left, center, selected "other" options) is both the fact of remaining in the opposition and the general raising of the level of the tension of public debate (which is also reflected in the answers to question 12). The answers referring to undemocratic methods of resolving a political dispute, coming from people declaring respect for constitutional rights and freedoms (two questions earlier), are particularly striking. They include postulates to ban selected political parties, religious associations, calls for armed uprisings and/or population resettlement. ${ }^{9}$ However, there are only 14 cases of such statements.

\section{Bibliography}

\section{Written sources:}

Almond G., Verba S. (1989), The Civic Culture. Political Attitudes and Democracy in Five Nations, London.

Antoszewski A., Herbut R. (2001), Systemy polityczne wspótczesnego świata, Gdańsk.

Bierzanek R., Symonides J. (2005), Prawo międzynarodowe publiczne, Warszawa.

Dijk van J. (2010), Społeczne aspekty nowych mediów. Analiza społeczeństwa sieci, Warszawa.

Economist Intelligence 2019.

Habermas J. (2007), Strukturalne przeobrażenia sfery publicznej, Warszawa.

Huntington S. (2006), Zderzenie cywilizacji i nowy kształt ładu światowego, Warszawa.

Kaniewska-Sęba A., Pająk-Patkowska B. (2017), Negative recommendation in social media - theoretical approach and case studies, „Przegląd Politologiczny”, nr 3, s. 45-60.

Milbrath L.W., Goel L. (1977), Political Participation: How and why Do People Get Involved in Politics, New York.

${ }^{9}$ It is worth remembering that, according to international law, forced displacement of people is a crime against humanity (Bierzanek, Symonides, 2005, s. 353-355). 
Mouffe Ch. (2005), Paradoks demokracji, Wrocław.

Pałubicka A. (2013), Gramatyka kultury europejskiej, Bydgoszcz.

Pariser E. (2011), The Filter Bubble: What the Internet Is Hiding from You, London.

Pawlak P. (2014), Обобществление политических дискуссий на примере интернете: агрессия и поиск компромисса - анализ конкретного случая, „Известия Иркутского государственного университета. Серия психология”, t. 9, s. 57-68.

Pawlak P. (2016), Charakter dyskusji politycznej na portalach informacyjnych. Studium przypadku, „Studia Europaea Gnesnensia”, nr 13, s. 201-224.

Pawlak P., Strzelecki W. (2012), Deindywidualizacja w Sieci $i$ w środowisku wielkomiejskim, „Zeszyty Naukowe Uniwersytetu Szczecińskiego: Studia Informatica”, nr 29, Szczecin.

Rybicki P. (1979), Struktura społecznego świata: studia z teorii społecznej, Państwowe Wydawnictwo Naukowe, Warszawa.

Szczepankowski R. (2020), To jest wojna! Protestów ciąg dalszy, „Gazeta Wyborcza”, 2 listopada.

Wiatr J. (1999), Socjologia polityki, Warszawa.

Więckiewicz M. (2013), "Lubię to", czyli angażuję się? Analiza typowanych dla slaktywizmu działań internetowych w odniesieniu do koncepcji "pokolenie leni«, w: Transformacje rzeczywistości. Przejawy aktywizmu w kulturze, mediach i polityce, red. M. Babecki, F. Pierzchalski, Kraków, s. $133-134$.

Zuba K. (2015), Pomiędzy pragmatyzmem a radykalizmem. Ideologia w dobie postideologii, w: Ideologie doktryny ruchy społeczne i polityczne, eds. M. Marczewska-Rytko, W. Ziętara, Lublin.

\section{E-sources:}

Ahlgren M. (2020), Statystyki Facebooka dla 2020, https://www.websitehostingrating.com/pl/facebook-statistics/, Jan 2021.

Christensen H. (2011), Political activities on the Internet: Slacktivism or political participation by other means?, https://firstmonday.org/article/view/3336/2767, Feb 2021.

Democracy Indeks (2019), [w:] Economist Intelligence Unit, https://www.eiu.com/topic/democracyindex, Jan 2021.

Dziermański A. (2019), Twitter rezygnuje z reklam politycznych. Zupelnie inaczej niż Facebook, Telepolis, https://www.telepolis.pl/wiadomosci/aplikacje-i-rozrywka/twitter-reklamy-politycznefacebook, Jan 2021.

Freedom House Reports (2020), Freedom House, https://freedomhouse.org/about-us/board-leadership, Jan 2021.

Hitlin P., Rainie L. (2019), Facebook Algorithms and Personal Data, Pew Research Center, https:// www.pewresearch.org/internet/2019/01/16/facebook-algorithms-and-personal-data/, Jan 2021.

Jasińska A. (2020), Czy czeka nas wojna domowa, Rafał Trzaskowski - Ruch Wspólna Polska, https:// www.facebook.com/groups/508009376719939/permalink/738590873661787, Jan 2021.

Kaczyński J. (2020), Oświadczenie Prezesa PiS, Wicepremiera Jarosława Kaczyńskiego, Prawo i Sprawiedliwość, http://pis.org.pl/aktualnosci/oswiadczenie-prezesa-pis-wicepremiera-jaroslawa-kaczynskiego, 30.10.2020.

Kosiński M. (2017), https://www.vice.com/en/article/mg9vvn/how-our-likes-helped-trump-win, Jan 2021.

Press Freedom Index (2020), Reporters Without Borders, https://rsf.org/en/ranking/2020, Jan 2021.

Reporters Without Borders, 2020

Rogulski A. (2020), Uzytkownicy social media w Polsce i na świecie, https://www.whysosocial.pl/ uzytkownicy-social-media-w-polsce-i-na-swiecie/, Jan 2021. 
Wenzel M. (2017), Media a poglady polityczne, https://www.swps.pl/centrum-prasowe/informacjeprasowe/18355-media-a-poglady-polityczne, Jan 2021.

\section{Spór polityczny w Polsce, w oczach facebookowych slaktywistów}

\section{Streszczenie}

Niniejszy tekst jest raportem z badań nad wybranymi aspektami kryzysu demokracji w Polsce. Problem analizy koncentruje się na pytaniach o stosunek uczestników sporu politycznego do przeciwników, możliwości (i sposobu) osiągnięcia porozumienia oraz oceny sytuacji. Obszar analizy wybrałem, traktując media społecznościowe jako przejrzystą platformę do sporu politycznego (szczególnie podczas pandemii SARS-CoV-2). Istotą badania było znalezienie respondentów wyraźnie zaangażowanych w spór polityczny. Autor wskazał portal Facebook między innymi dlatego, że platforma ta tworzy miejsce dla wielu aktywnie działających grup tematycznych, skupiających zwolenników poszczególnych opcji politycznych. Fakt ten ułatwia dotarcie do respondentów o preferowanych cechach. Badanie przeprowadzono w okresie od 13.12.2020 r. Do 25.01.2021 r. Na podstawie autorskiego formularza składającego się z 15 pytań. Próba badawcza liczy 220 respondentów: 126 kobiet i 94 mężczyzn w wieku od 14 do 72 lat. Odpowiednio do charakteru zmiennych i liczebności próby obliczono współczynnik kontyngencji i test Kruskala-Wallisa oraz istotność statystyczną uzyskanych wyników. Wszystkie analizy wykonano w oparciu o oprogramowanie SPSS w wersji 26 i Microsoft Excel.

Słowa kluczowe: kryzys demokracji, mowa nienawiści, lenistwo, media społecznościowe 
